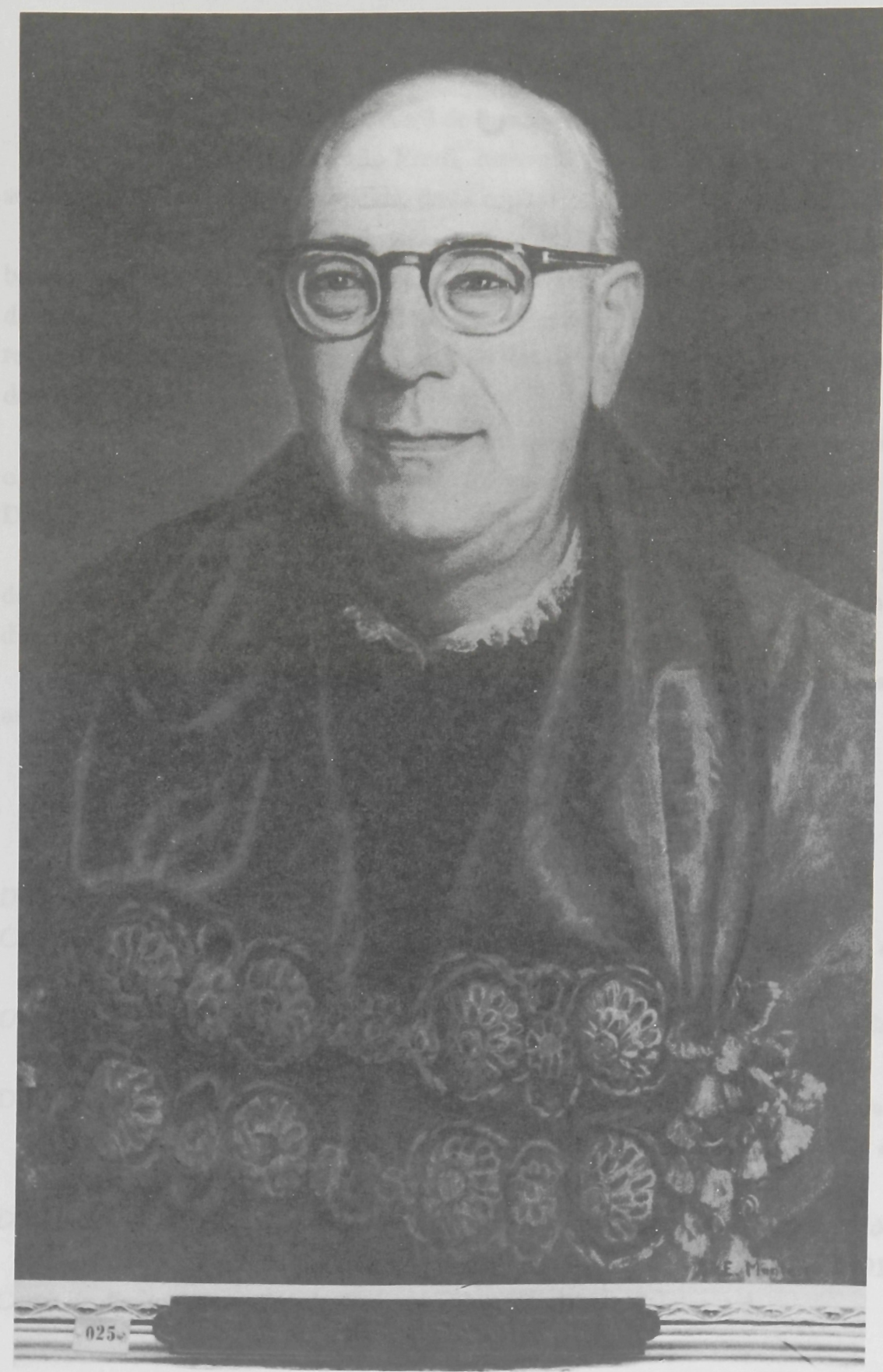





\section{BRAZ DE SOUSA ARRUDA}

(1949-1955)

Nasceu em Campinas a 3 de fevereiro de 1895.

Criado em Ribeirão Preto, cursou o Ginásio de Estado local e, a seguir, o Instituto Silvio de Almeida, desta capital.

Em 1912, matriculou-se na Faculdade de Direito de São Paulo, bacharelando-se em 1916. No ano seguinte, abriu-se o concurso para substituto da cadeira de Economia Política, Ciência das Finanças e Direito Administrativo, tendo sido aprovado, por unanimidade de votos; em 1919 foi nomeado livredocente.

Em 1920, foi aprovado em novo concurso, ocasião em que recebeu o grau de doutor. Em maio de 1925, foi nomeado professor catedrático de Direito Internacional Público.

Durante os estudos jurídicos, secretariou o Centro Acadêmico XI de Agosto. Foi nomeado membro do Conselho Administrativo do Estado e diretor da Faculdade de Direito de São Paulo, de 1949 a 1955.

Além das obras elencadas a seguir, é autor de vários pareceres e artigos publicados na Revista da Faculdade de Direito e na Revista Jurídica.

Faleceu a 24 de junho de 1963.

\section{Obras Publicadas}

Discursos acadêmicos. São Paulo : s.l.p., 1916.

Concurso de economia politica: preleçāo proferida perante a Congregaçāo da Faculdade de Direito de São Paulo. São Paulo : Piratininga, 1917.

O salário: trabalho apresentado para o concurso da Faculdade de Direito de São Paulo. São Paulo : Piratininga, 1917.

Diferenssa entre direito administrativo e sciencia da administração: constituem o direito administrativo e a sciencia da administração distinctas?, Revista da Faculdade de Direito de São Paulo, São Paulo, v. 21, p. 61-96, 1913.

Direito das gentes, direito internacional privado, direito constitucional: dissertações apresentadas à Faculdade de Direito de São Paulo. São Paulo : Siqueira, 1919. Curso de direito internacional: na era atomica. Curitiba : Guaíra, s.d.. 
Ruy Barbosa e direito das gentes. Revista da Faculdade de Direito de São Paulo, São Paulo, v. 40, p. 17-25, 1945.

A Faculdade de Direito, a Universidade e os problemas do ensino. Revista da Faculdade de Direito de São Paulo, São Paulo, v. 41, p. 37, 1946.

Progresso e futuro do direito internacional. Revista da Faculdade de Direito de São Paulo, São Paulo, v. 23, p. 201-207, 1926-27. 